\title{
Response of Bobwhites to Cover Changes within Three Grazing Systems
}

\author{
MARCIA M. HAMMERQUIST-WILSON AND JOHN A. CRAWFORD
}

\begin{abstract}
In south Texas bobwhites responded to short-term changes in the amount of vegetative cover within three grazing systems, two rotational and one continuous. Use by quail apparently was related to increases in amounts of bare ground and forb cover and decreases in grass cover.
\end{abstract}

Throughout much of the range of the bobwhite (Colinus virginianus), grazing by cattle is a common land-use practice, yet the understanding of the effects of grazing on bobwhite populations is incomplete. Grazing possibly was responsible for the westward extension of the distribution of bobwhites in early post-settlement times because of the invasion of weeds and brush into grasslands (Edminster 1954). Nevertheless, Murray (1958) reported that overgrazing diminished the food supply and reduced escape cover in bobwhite habitat. Snyder (1978) observed that during the winter heavily grazed river bottoms did not provide adequate cover for bobwhites. Klimstra and Scott (1957) found little or no use by nesting bobwhites where heavy grazing occurred. Johnsgard (1973) noted that bobwhites existed in large numbers in western and southern Texas wherever excessive grazing did not occur. Jackson (1969) found overgrazing reduced the concealment value of escape cover; however, he stated that heavy grazing on small areas resulted in increased amounts of food for quail. After 3 years of research in the West Texas Rolling Plains, Boyd (1977) suggested that moderate grazing was more conducive to maintaining large quail populations than were light or heavy grazing pressures. However, none of these authors investigated alternatives to traditional grazing methods. Edminster (1954) proposed rotational grazing as a favorable management practice for bobwhites and Jackson (1969) suggested that the best management of nesting cover was range deferment or pasture rotation, but no data were presented. Therefore, this study was developed to determine the short-term changes in bobwhite occurrence and habitat among and within three grazing systems, two rotational and one continuous, in south Texas.

\section{Methods}

During spring and fall of 1976 and 1977 , field research was conducted on the Rob and Bessie Welder Wildlife Refuge, located approximately $80 \mathrm{~km}$ northeast of Corpus Christi, Texas. The Refuge has a history of grazing both by cattle and native wildlife. In 1975, two types of rotational grazing systems for cattle were implemented, high intensity-low frequency (HILF) and fourpasture, deferred-rotation (4PDR). The HILF system entailed rotation of one herd on seven pastures; a variable 3-week to 7-week grazing period was used. Each of the seven pastures was grazed twice within a 12-month period and deferred for 6 months between each period. Within the 4PDR system, three herds were rotated on

\footnotetext{
Authors are research fellow, Rob and Bessie Welder Wildlife Foundation, Sinton, Texas, 78387, and associate professor, Department of Fisheries and Wildlife, Oregon State University, Corvallis, Oregon 97331.

This article is Rob and Bessie Welder Wildlife Foundation Publication No. 263 and is Technical Paper No. 5284 of the Oregon Agricultural Experiment Station. R.G. Anthony and W.C. Krueger provided comments on the manuscript. Manuscript received September 14, 1979.
}

four pastures with one pasture deferred. One herd was rotated every 4 months to the deferred pasture. In addition, a continuously grazed system (CONT) was established with year-round grazing. Yearly stocking rates were 5 ha per animal unit on all systems.

In one pasture of each of the three grazing systems, two 16-ha study areas were selected on Victoria clay soils. The vegetation was characterized by a mesquite (Prosopis glandulosa)-mixed grass plant community (Drawe et al. 1978). On each of the six study areas ten locations were selected randomly at which permanent 30.5-m transects were established. Along each transect herbaceous cover was sampled with a point frame (Brown 1954) at three equidistant, fixed intervals during each sampling period. The first plant or bare ground encountered with each pin of the frame was recorded. Plants were categorized by life-form (grass, forb, or dead vegetative material) and by height class. Additionally, shrub cover was determined along each transect with the line interception method (Canfield 1941) during fall 1976 and spring 1977.

Four methods were used to obtain indices to quail occurrence: 1) The total numbers of quail observed along a $1-\mathrm{km}$ transect (one per study area) were recorded, with each transect surveyed 50 times throughout each sampling period.

2) Trapping was conducted with baited traps during alternate weeks from mid-April to mid-June and during September and October, and the total numbers of different individuals were recorded.

3) Censuses were conducted with a bird dog, and the numbers of quail flushed were used to develop indices of abundance. Each study area was censused systematically once during spring 1976 and four times during each subsequent sampling period.

4) Total numbers of bob-white calls (male vocalizations) in spring and of roost calls (vocalizations uttered by both sexes prior to leaving the roost) in fall were recorded in each grazing system. Counts began at $15 \mathrm{~min}$ before sunrise and lasted $75 \mathrm{~min}$. One count and six counts per sampling period were conducted in 1976 and 1977 , respectively.

Within a grazing system paired $t$-tests were used to compare each life-form category of herbaceous cover and shrub cover between sampling periods. To determine differences in vegetative cover among the grazing systems during a sampling period, one-way analysis of variance was used. Duncan's new multiple-range test was used for separation of means (Steel and Torrie 1960). Each index of quail occurrence was compared between sampling periods with a signed rank test if the two sample sizes were equal; a rank sum test was used if the sample sizes were unequal (Hollander and Wolfe 1973). To determine differences in quail occurrence among the three grazing systems, each of the indices was compared separately during each period by use of simultaneous comparison of rank sum test (D. Thomas, personal communication). Fiducial limits for all statistical analyses were established at the $95 \%$ confidence level.

\section{Results}

Analysis of vegetative data indicated significantly more forb cover on the CONT pasture than on the HILF or the 4PDR 
Table 1. Comparison of relative composition of cover and bare ground on three grazing systems,1 Welder Wildlife Refuge, Texas, 1976-1977.

\begin{tabular}{lccccc}
\hline & & \multicolumn{4}{c}{ Relative composition } \\
\cline { 3 - 6 } Life-form category & Treatment & 1976 & 1976 & 1977 & 1977 \\
\hline Grasses & HILF & $60^{\mathrm{a}} 3$ & $57^{\mathrm{a}}$ & $36^{\mathrm{a}_{4}}$ & $26^{\mathrm{a}_{4}}$ \\
& 4PDR & $82^{\mathrm{b}}$ & $69^{\mathrm{b}_{4}}$ & $57^{\mathrm{b}_{4}}$ & $47^{\mathrm{b}_{4}}$ \\
& CONT & $66^{\mathrm{a}}$ & $58^{\mathrm{a}}$ & $56^{\mathrm{b}}$ & $54^{\mathrm{b}}$ \\
Forbs & HILF & $14^{\mathrm{a}}$ & $14^{\mathrm{b}}$ & $30^{\mathrm{b}_{4}}$ & $17^{\mathrm{b}_{4}}$ \\
& 4PDR & $8^{\mathrm{a}}$ & $5^{\mathrm{a}} \mathrm{a}_{4}$ & $21^{\mathrm{a}_{4}}$ & $4^{\mathrm{a}_{4}}$ \\
& CONT & $22^{\mathrm{b}}$ & $22^{\mathrm{c}}$ & $24^{\mathrm{a}}$ & $14^{\mathrm{b}_{4}}$ \\
Dead plants & HILF & $22^{\mathrm{b}}$ & $21^{\mathrm{a}}$ & $26^{\mathrm{b}}$ & $49^{\mathrm{a}_{4}}$ \\
& 4PDR & $10^{\mathrm{a}}$ & $23^{\mathrm{a}_{4}}$ & $17^{\mathrm{a}_{4}}$ & $47^{\mathrm{a}_{4}}$ \\
& CONT & $12^{\mathrm{a}}$ & $18^{\mathrm{a}_{4}}$ & $16^{\mathrm{a}}$ & $30^{\mathrm{a}_{4}}$ \\
Bare ground & HILF & $4^{\mathrm{b}}$ & $8^{\mathrm{b}_{4}}$ & $8^{\mathrm{a}}$ & $8^{\mathrm{b}}$ \\
& 4PDR & $0^{\mathrm{a}}$ & $3^{\mathrm{a}}$ & $5^{\mathrm{a}}$ & $2^{\mathrm{a} 4}$ \\
& CONT & $0^{\mathrm{a}}$ & $2^{\mathrm{a} 4}$ & $4^{\mathrm{a}}$ & $2^{\mathrm{a}}$
\end{tabular}

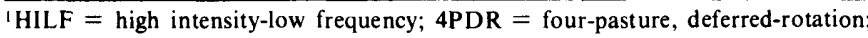
CONT $=$ continuous

${ }^{2}$ Average of two study areas.

${ }^{3}$ Within each life-form category column values followed by different superscripts are significantly different.

${ }^{4}$ Significant change from preceding sample period.

pastures during spring and fall of 1976 (Table 1). From fall 1976 to spring 1977, a significant increase in forb cover was observed on both rotational grazing systems (Table 1). By spring 1977, the HILF system had significantly more forb cover than either of the other systems (Table 1). Dry conditions during the second summer probably caused the significant decline in forb cover on all the pastures (Table 1). Furthermore, in fall $1977,80 \%$ of the forbs in HILF were in the tall height category $(>40 \mathrm{~cm})$, the greatest amount during any period. Significantly more grass cover existed on the 4PDR pasture than on either of the other two pastures during 1976 (Table 1). From fall 1976 to fall 1977, a significant decline occurred in the amount of grass cover on both rotational grazing systems (Table 1). Throughout the 1977 sampling periods, HILF system had significantly less grass cover than the other systems (Table 1). The amount of bare ground was significantly greatest on the HILF system during the study except for spring 1977 (Table 1).

No significant difference in the shrub cover occurred among the three pastures during fall 1976 (HILF 10\%, 4PDR 6\%, and CONT $10 \%$ ) or during spring 1977 (HILF 13\%, 4PDR 11\%, and CONT $12 \%$ ). However, brush cover increased significantly on all three systems from fall to spring

During spring 1976, significantly more bob-white calls were recorded in the HILF pasture than in the CONT pasture and significantly more calls were recorded in the CONT pasture than in the 4PDR (Table 2). During the other three sampling periods, none of the four population indices yielded significant differences among the grazing systems.

However, within each grazing system some changes in the occurrence of bobwhites were noted from one sampling period to another. From fall 1976 to spring 1977, numbers of quail observed increased significantly on the 4PDR system and numbers of quail flushed declined significantly on the CONT system (Table 2). Likewise, when indices from spring 1976 were compared to spring 1977 , a significant increase occurred in the number of bob-white calls on the 4PDR area and significantly fewer quail were trapped on the CONT area. In addition, the numbers of quail flushed declined significantly on 4PDR between spring and fall 1977 (Table 2). During this time the numbers of quail flushed increased significantly on the HILF pasture (Table 2).

\section{Discussion}

In addition to the few significant differences in use by quail able 2. Indices to bobwhite occurrence on three grazing systems,' Welder Wildlife Refuge, Texas, 1976-1977.

\begin{tabular}{|c|c|c|c|c|c|}
\hline \multirow[b]{2}{*}{ Treatment } & \multirow[b]{2}{*}{ Method } & \multicolumn{4}{|c|}{ Occurrence indices } \\
\hline & & $\begin{array}{c}\text { Spring } \\
1976\end{array}$ & $\begin{array}{l}\text { Fall } \\
1976\end{array}$ & $\begin{array}{c}\text { Spring } \\
1977\end{array}$ & $\begin{array}{c}\text { Fall } \\
1977\end{array}$ \\
\hline \multirow[t]{4}{*}{ HILF } & Observations & $26^{4}$ & 48 & 45 & 92 \\
\hline & Trapping & $3^{4}$ & 13 & 9 & 35 \\
\hline & Flush census ${ }^{2}$ & 11 & 29 & 18 & $68^{5}$ \\
\hline & Vocalizations $^{3}$ & 631 & 197 & 2424 & 1039 \\
\hline \multirow[t]{4}{*}{ 4PDR } & Observations & 11 & 16 & $37^{5}$ & 19 \\
\hline & Trapping & 2 & 6 & 9 & 10 \\
\hline & Flush census ${ }^{2}$ & 4 & 18 & 11 & $0^{5}$ \\
\hline & Vocalizations $^{3}$ & 85 & 135 & 2327 & 1013 \\
\hline \multirow[t]{4}{*}{ CONT } & Observations & 53 & 37 & 18 & 47 \\
\hline & Trapping & 16 & 18 & 6 & 6 \\
\hline & Flush census ${ }^{2}$ & 11 & 42 & $4^{5}$ & 25 \\
\hline & Vocalizations $^{3}$ & 194 & 101 & 1558 & 521 \\
\hline
\end{tabular}

${ }^{1}$ HILF $=$ high intensity-low frequency; 4PDR = four-pasture, deferred-rotation; CONT $=$ continuous

${ }^{2}$ Values indicate total number of quail flushed once during spring 1976 and four times during subsequent sampling periods.

${ }^{3}$ Values indicate total number of vocalizations recorded once during each sampling period in 1976 and six times during each sampling period in 1977. ${ }^{4}$ Data were collected only during latter one-half of sampling period.

s Significant $(P \geq 0.05)$ change from preceding sample period.

among the three grazing systems, several general, albeit statistically nonsignificant, trends developed. Use by quail was greatest on the HILF system throughout 1976-1977, whereas, the least amount of use occurred on 4PDR (Table 2). One exception occurred during spring 1977, when the fewest numbers of quail were observed on the CONT pasture (Table 2).

Greater use of HILF study areas probably occurred in response to the presence of the greatest amount of bare ground, the least amount of grass cover and, during fall 1977, the large amount of tall forbs. Scott and Klimstra (1954) found that bare ground was an important component of bobwhite habitat in providing a desirable surface for movement and feeding. Klimstra and Ziccardi (1963) also noted a strong preference of bobwhites for bare or nearly bare ground as roosting substrate with low, sparse herbaceous plants as the roosting cover. Stoddard (1931) found few quail in areas of dense grass; dense stands of grass supported few preferred food items (Kiel 1976) and made seeds unavailable to quail (Jackson 1969). Tall forbs provided overhead concealment for feeding and moving and probably were an important source of food since forbs represent approximately $60 \%$ of the bobwhite diet during fall (Jackson 1969).

Fluctuations in use by quail on the 4PDR system apparently coincided with the amount of forb cover. Use was high when the forb cover was highest (21\% during spring 1977) and low when the forb cover was below $8 \%$. When use by quail was high on 4PDR, use was low on the CONT, despite nearly comparable vegetative composition of the two systems (Tables 1 and 2). A possible explanation for the apparent discrepancy was that the presence of standing water in one study a rea in the CONT pasture may have led to reduced use by quail.

Controlled grazing treatments on the Welder Refuge had few effects on the vegetation during the 2 years of this study; however, above-average rainfall in 1976 may have affected the response of the vegetation to the treatments. Correspondingly, few definitive relationships between grazing systems and use by quail were found. Nevertheless, changes in use by quail through time within a system seemingly were related to certain habitat factors which were influenced by the grazing system and the climate. Long-term changes in habitat resulting from the grazing systems are unknown and merit investigation.

\section{Literature Cited}

Boyd, C.E. 1977. Effects of livestock grazing on vegetation, quail popula- 
tions, hunter harvest rates, and beef production. Tcxas Parks and Wildl. Dep. Final Proj. Rep. Fed. Aid Wildl. Restoration, Proj. W-88-R-16. $65 \mathrm{p}$.

Brown, D. 1954. Methods of Surveying and Measuring Vegetation. Commonwealth Bureau of Pastures and Field Crops, Hurley, Berks, England $223 \mathrm{p}$.

Canfield, R.H. 1941. Application of the line interception method in sampling range vegetation. J. Forest. 39:388-394.

Drawe, D.L., A.D. Chamrad, and T.W. Box. 1978. Plant communities of the Welder Wildlife Refuge. Rob and Bessie Welder Wildlife Foundation, Sinton, Tex. Contrib. 5, Ser. B, revised. 38 p.

Edminster, F.C. 1954. American Game Birds of Field and Forest. Charles Scribner's Sons, New York, N.Y. 490 p.

Hollander, M., and D.A. Wolfe. 1973. Nonparametric Statistical Methods. John Wiley and Sons, New York, N.Y. 503 p.

Jackson, A.S. 1969. A handbook for bobwhite quail management in the West Texas Rolling Plains. Texas Parks and Wildl. Dep. Bull. 48.77 p.

Johnsgard, P.A. 1973. Grouse and Quails of North America. Univ. of Nebraska Press, Lincoln. 553 p.
Kiel, W.H., Jr. 1976. Bobwhite quail population characteristics and management implications in south Texas. Trans. N. Amer. Wildl. Nat. Resour. Conf. 41:407-420.

Klimstra, W.D., and T.G. Scott. 1957. Progress report on bobwhite nesting in southern Illinois. Proc. Southeastern Ass. Game and Fish Commissioners 11:351-355.

Klimstra, W.D., and V.C. Ziccardi. 1963. Night-roosting habitats of bobwhites. J. Wildl. Manage. 27:202-214.

Murray, R.W. 1958. The effect of food plantings, climatic conditions and land use practices upon the quail population on an experimental area in northwest Florida. Proc. Southeastern Ass. Game and Fish Commissioners 12:269-274.

Scott, T.T., and W.D. Klimstra. 1954. Report on a visit to quail management areas in southeastern United States. Illinois Wildl. 9:5-9.

Snyder, W.D. 1978. The bobwhite in eastern Colorado. Colo. Div. Wildl., Game Res. Sec. Fed. Aid Proj. W-37-R. Tech. Publ. No. 32. 88 p.

Steel, R.G.D., and J.H. Torrie. 1960. Principles and Procedures of Statistics. McGraw-Hill Book Company, New York, N.Y. 481 p.

Stoddard, H.L. 1931. The Bobwhite Quail, Its Habits, Preservation and Increase. Charles Scribner's Sons, New York, N.Y. 559 p. 